\title{
Springer
}

\section{Stimulation of reflection and discussion in museum visits through the use of social media}

\author{
Social Network Analysis and Mining \\ December 2017, 7:40 | Cite as \\ Original Article
}

First Online: 23 August 2017

152

Downloads

\section{Abstract}

In this paper, we examine how social media can be linked to cultural heritage and in particular how we can incorporate games, social networks, history reflection and culture. More specifically, we explore the following aspects: (a) how social media sites can be integrated into the museum user experience (b) how user interactions within the social media, both within the context of the museum experience and outside it, can be exploited to enhance the quality of recommendations made to the users, (c) how trending topics from social media can be used to link museum exhibits with today's topics of interest and (d) how multi-level related terms extraction from social media data can lead to proposals for reflections to users. The end goal is to provide increased stimuli for users to study exhibits deeper and reflect on them, as well as to trigger discussion between the users, thus maximizing the impact of a museum visit.

\section{Keywords}

Social networks User profiling Cognitive style Reflection 
Communication Big data

\section{This is a preview of subscription content, log in to check access}

\section{Notes}

\section{Acknowledgements}

This work has been realized within the project CrossCult: "Empowering reuse of digital cultural heritage in context-aware crosscuts of European history," funded by the European Union's Horizon 2020 research and innovation program, Grant\#693150.

\section{References}

Anagnostopoulos A, Kumar R, Mahdian M (2008) Influence and correlation in social networks. In: Proceedings of the 14th ACM SIGKDD international conference on Knowledge discovery and data mining (KDD '08), pp 7-15 Google Scholar

Antoniou A, Lepouras G, Lykourentzou I, Naudet Y (2013) Connecting physical space, human personalities, and social networks: the Experimedia Blue project. In: Proceedings of the International Biennial Conference Hybrid City, Subtle Revolutions, pp 23-25

Google Scholar

Apache Group (2017) Apache Solr. http://lucene.apache.org/solr/ (http://lucene.apache.org/solr/). Accessed 10 Jan 2017

Bakshy E, Rosenn I, Marlow C, Adamic L (2012a) The role of social networks in information diffusion. In: Proceedings of the 21st international conference on World Wide Web, pp 519-528 Google Scholar

Bakshy E, Eckles D, Yan R, Rosenn I (2012b) Social influence in social advertising: evidence from field experiments. In: Proceedings of the 13th ACM Conference on Electronic Commerce (2012) Google Scholar Bampatzia S, Antoniou A, Lepouras G, Vassilakis C, Wallace M (2016) 
Using social media to stimulate history reflection in cultural heritage. In: 11th International Workshop on Semantic and Social Media Adaptation and Personalization (SMAP 2016), 20-21 October, Thessaloniki, Greece Google Scholar

Berryman J (2013) Semantic search in numpy. https://github.com /o19s/SemanticSearchInNumpy (https://github.com /o19s/SemanticSearchInNumpy). Accessed 10 Jan 2017

Dümcke C, Gnedovsky M (2013).The social and economic value of cultural heritage: literature review. EENC paper

Google Scholar

EGMUS (2017) European Group on Museum Statistics.

http://www.egmus.eu/ (http://www.egmus.eu/). Last accessed on 10 Jan 2017

Emotive Virtual cultural Experiences through personalized storytelling (EMOTIVE), EU Project ID: 727188. http://www.emotiveproject.eu/ (http://www.emotiveproject.eu/). Accessed 6 May 2017

European Union (2007) Treaty of Lisbon amending the Treaty on European Union and the Treaty establishing the European Community. Off J Eur Union, vol. 50, notice no 2007/C 306/01

Google Scholar

Falk JH, Koran L, Dierking D, Dreblow L (2010) Predicting visitor behavior. Curator Mus J 28(4):249-258

CrossRef Google Scholar

Farnadi G, Sitaraman G, Sushmita S, Celli F, Kosinski M, Stillwell D, Davalos S, Moens M-F, de Cock M (2016) Computational personality recognition in social media. User Model User-Adapt Interact

26(2-3):109-142

CrossRef

Google Scholar

Fletcher A, Lee MJ (2012) Current social media uses and evaluations in American museums. Mus Manag Curatorship 27(5):505-521

CrossRef

Google Scholar

Gaeta A, Gaeta M, Ritrovato P (2007) A grid based software architecture for delivery of adaptive and personalised learning experiences. Pers

Ubiquitous Comput 13(3):207-217

CrossRef

Google Scholar

Gilbert E, Karahalios K (2009) Predicting tie strength with social media. In: Proceedings of the SIGCHI Conference on Human Factors in Computing Systems (CHI 'o9), pp 211-220

Google Scholar

Goh KY, Ping JW (2014) Engaging consumers with advergames: an 
experimental evaluation of interactivity, fit and expectancy. J Assoc Inf

Syst 15(7):388-421

Google Scholar

Granic I, Lobel A, Engels RCME (2014) The benefits of playing video games. Am Psychol 69(1):66-78

CrossRef

Google Scholar

Greffe X (2004) La valorisation économique du patrimoine. La documentation française, Paris. ISBN: 2-11-094274-6

Google Scholar

Hsi S (2004) I-guides in progress: two prototype applications for museum educators and visitors using wireless technologies to support informal science learning. In: Proceedings of the 2nd IEEE International Workshop on Wireless and Mobile Technologies in Education, p 187 Google Scholar

Konert J (2014) Using social media interactions for personalization and adaptation in digital games. In: Proceedings of the European Conference on Social Media: ECSM 2014, p 263

Google Scholar

Konert J (2015) Game adaptation and personalization support. In: Interactive multimedia learning. Springer Theses (Recognizing Outstanding Ph.D. Research). Springer, Cham, pp 73-81

Google Scholar

Kwak H, Lee C, Park H, Moon S (2010) What is Twitter, a social network or a news media? In: Proceedings of WWW 10, pp 591-600

Google Scholar

Licciardi G, Amirtahmasebi R (2012) The economics of uniqueness:

investing in historic city cores and cultural heritage assets for sustainable development. World Bank, Washington DC

CrossRef

Google Scholar

Margaris D, Vassilakis C, Georgiadis P (2016) Recommendation information diffusion in social networks considering user influence and semantics. Soc Netw Anal Min 6(1):108:1-108:22

CrossRef

Google Scholar

Muntean CH, Muntean G-M (2007) Open corpus architecture for personalised ubiquitous e-learning. Pers Ubiquitous Comput

13(3):197-205

CrossRef

Google Scholar

Myers I, McCaulley M, Most R (1985) Manual, a guide to the development and use of the Myers-Briggs type indicator. Consulting Psychologists

Press, Palo Alto, CA 


\section{Google Scholar}

Naudet Y, Lykourentzou I, Tobias E, Antoniou A, Rompa J, Lepouras G (2013) Gaming and cognitive profiles for recommendations in museums. In: Proceedings of SMAP 2013, IEEE Computer Society, pp 67-72 Google Scholar

Naudet Y, Antoniou A, Lykourentzou I, Tobias E, Rompa J, Lepouras G (2015) Museum personalization based on gaming and cognitive styles. Int J Virtual Communities Soc Netw 7(2):1-30

CrossRef

Google Scholar

Oechslein O, Hess T (2014) The value of a recommendation: the role of social ties in social recommender systems. In: Sprague RH Jr (ed) Proceedings of the 47th Hawaii international conference on system science. IEEE CPS

Google Scholar

Oppermann R, Specht M (1998) Adaptive support for a mobile museum guide. In: Proceedings of IMC'98 Workshop on Interactive Applications of Mobile Computing, Rostock, Germany

Google Scholar

Pluggable Social Platform for Heritage Awareness and Participation (PLUGGY), EU Project ID: 726765. https://www.pluggy-project.eu/ (https://www.pluggy-project.eu/). Accessed 6 May 2017

Pujol L, Roussou M, Poulou S, Balet O, Vayanou M, Ioannidis Y (2008)

Personalizing interactive digital storytelling in archaeological museums: the CHESS project. In: Proceedings of 4oth annual conference of computer applications and quantitative methods in archaeology Google Scholar

Reeves B, Read JL (2013) Total engagement: how games and virtual worlds are changing the way people work and businesses compete.

Harvard Business Press, Cambridge

Google Scholar

Russo A, Watkins J, Groundwater-Smith S (2009) The impact of social media on informal learning in museums. Educ Media Int 46(2):153-166

CrossRef

Google Scholar

Serrell B (1997) Paying attention: the duration and allocation of visitors' time in museum exhibitions. Curator Mus J 40(2):108-125

CrossRef

Google Scholar

Twitter (2017a) GET trends/place documentation page.

https://dev.twitter.com/rest/reference/get/trends/place

(https://dev.twitter.com/rest/reference/get/trends/place). Accessed 9

Jan 2017

Twitter (2017b) GET search/tweets documentation page. 
https://dev.twitter.com/rest/reference/get/search/tweets

(https://dev.twitter.com/rest/reference/get/search/tweets). Accessed 9

Jan 2017

van Hage WR, Stash N, Wang Y, Aroyo L (2010) Finding your way

through the Rijksmuseum with an adaptive mobile museum guide. In:

Aroyo L, Antoniou G, Hyvönen E, ten Teije A, Stuckenschmidt H, Cabral

L, Tudorache $\mathrm{T}$ (eds) The semantic web: research and applications.

Springer, Berlin, pp 46-59

CrossRef

Google Scholar

Vassilakis C, Antoniou A, Lepouras G, Wallace M, Lykourentzou I, Naudet $\mathrm{Y}$ (2016) Interconnecting objects, visitors, sites and (Hi)stories across cultural and historical concepts: the CrossCult project. In: Proceedings of the 6th International Euro-Mediterranean Conference: (EuroMed 2016), Nicosia, Cyprus

Google Scholar

Virtual Multimodal Museum (ViMM), EU Project ID: 727107.

http://www.vi-mm.eu/ (http://www.vi-mm.eu/). Accessed 6 May 2017

Wakkary R, Hatala M (2006) Situated play in a tangible interface and adaptive audio museum guide. Pers Ubiquitous Comput 11(3):171-191

CrossRef

Google Scholar

Weilenmann A, Hillman T, Jungselius B (2013) Instagram at the museum: communicating the museum experience through social photo sharing. In: Proceedings of the SIGCHI Conference on Human Factors in Computing Systems (CHI'13), ACM, pp 1843-1852

Google Scholar

Wong AS (2011) Ethical issues of social media in museums: a case study.

Mus Manag Curatorship 26(2):97-112

CrossRef

Google Scholar

\section{Copyright information}

\section{(C) Springer-Verlag GmbH Austria 2017}

\section{About this article}




\section{Cite this article as:}

Vassilakis, C., Antoniou, A., Lepouras, G. et al. Soc. Netw. Anal. Min. (2017) 7: 40. https://doi.org /10.1007/s13278-017-0460-3

\section{DOI (Digital Object Identifier)}

https://doi.org/10.1007/s13278-017-0460-3

\section{Publisher Name}

Springer Vienna

\section{Print ISSN}

1869-5450

\section{Online ISSN}

1869-5469

About this journal

Reprints and Permissions

\section{SPRINGER NATURE}

(C) 2017 Springer International Publishing AG. Part of Springer Nature. Not logged in · Not affiliated · 188.73.255.144 